How to cite: Rusz, O. (2019) Some Characteristics of Precipitation in the Central Region of Romania in the 1961-2017 Period. 2019 "Air and Water - Components of the Environment" Conference Proceedings, ClujNapoca, Romania, p. 299-310, DOI: 10.24193/AWC2019_30.

\title{
SOME CHARACTERISTICS OF PRECIPITATION IN THE CENTRAL REGION OF ROMANIA IN THE 1961-2017 PERIOD
}

\section{Ottilia RUSZ ${ }^{1}$ 冈}

\section{DOI: 10.24193/AWC2019_30}

\begin{abstract}
Monthly and yearly precipitation data (1961-2017) from six meteorological stations were analysed: Miercurea Ciuc (elevation $661 \mathrm{~m}$ ), Braşov (536 m), Sibiu (443 m), Cluj-Napoca (413 m), Târgu Mureş (308 m) and a mountain station, Lăcăuti $(1776 \mathrm{~m})$. The following precipitation data were studied: precipitation amounts, maximum 24 hours precipitation, number of days with solid and liquid precipitation, number of days exceeded $0.1,0.5,1.0,2.0,5.0,10.0,20.0,30.0 \mathrm{~mm}$. The standard deviation of yearly precipitation amount is the greatest in Lăcăuti $(208 \mathrm{~mm})$ and the smallest in Miercurea Ciuc $(94 \mathrm{~mm})$. Statistical significant trends in case of yearly precipitation amounts are characteristic for Cluj-Napoca (positive) and Lăcăuti (negative). Decreasing, statistical significant trends are indicated in case of number of days of solid precipitations (except Cluj-Napoca and Târgu Mureş). Generally, there are no changes in the number of days exceeding different thresholds, except Lăcăuti where decreasing, statistical significant trends are present in many cases. Two parts regression show 1982 as a moment of change in case of four stations. Based on the Palfai Drought Index, the driest years in Transylvania in the studied period were in 1987, 2003 and 2012 (when this index in some cases exceeded 6, which means moderate drought). In case of Lăcăuţi the PaDI values in all years are below 3, which means that no drought was present in this mountain area.
\end{abstract}

Keywords: precipitation, Central Romania, trends, drought index

\section{INTRODUCTION}

Precipitation is one of the most important meteorological parameters. It must be taken into account not only the amount of rainfall, but also the intensity or the distribution of precipitations. They represent the main source of water for plant growth and development. Climate changes led to an increase of surfaces affected by drought. In Romania drought affect especially south and south-eastern part of country (Sandu et al., 2010). Precipitation amount presents an increasing trend in north-western part of Romania, and decreasing trend in the eastern area (Marin et al., 2014). In the Carpathian Region, the rainy season lasts from May to July and the precipitation amount show a remarkable spatial variability. There is no significant trend of precipitations in the Carpathians in the period 1961-2010 (Spinoni et al., 2014). Based on Angot's monthly pluviometric index, Transylvania

\footnotetext{
${ }^{1}$ Meteorological Quality Service Târgu Mureş, Romania, e-mail: ruszotti@yahoo.com
} 
is included in Type II, which means that the annual variability of precipitation amount had a higher amplitude (Sandu et al., 2008). There are some differences not only regarding the elevation

\section{DATA AND METHODS}

Meteorological data from six weather stations located in Transylvania (s.s) were studied from the period 1961-2017: Miercurea Ciuc (elevation $661 \mathrm{~m}$ ), Braşov (536 m), Sibiu (443 m), Cluj-Napoca (413 m), Târgu Mureş (308 m) and a mountain station, Lăcăuti (1776 m) (Fig. 1). There are some differences not only regarding the elevation of these locations, but also the geographic position within the studied region. This affects the distribution of precipitation: in the eastern part there are less precipitation, while in the northern parts we deal with the highest amount of precipitation. Such as, average precipitation in Lăcăuţi is less than in Bucin (Gurghiu Mountains, $1282 \mathrm{~m}$ elevation), in spite of that Lăcăuţi is $500 \mathrm{~m}$ higher than Bucin (Rusz, 2012).

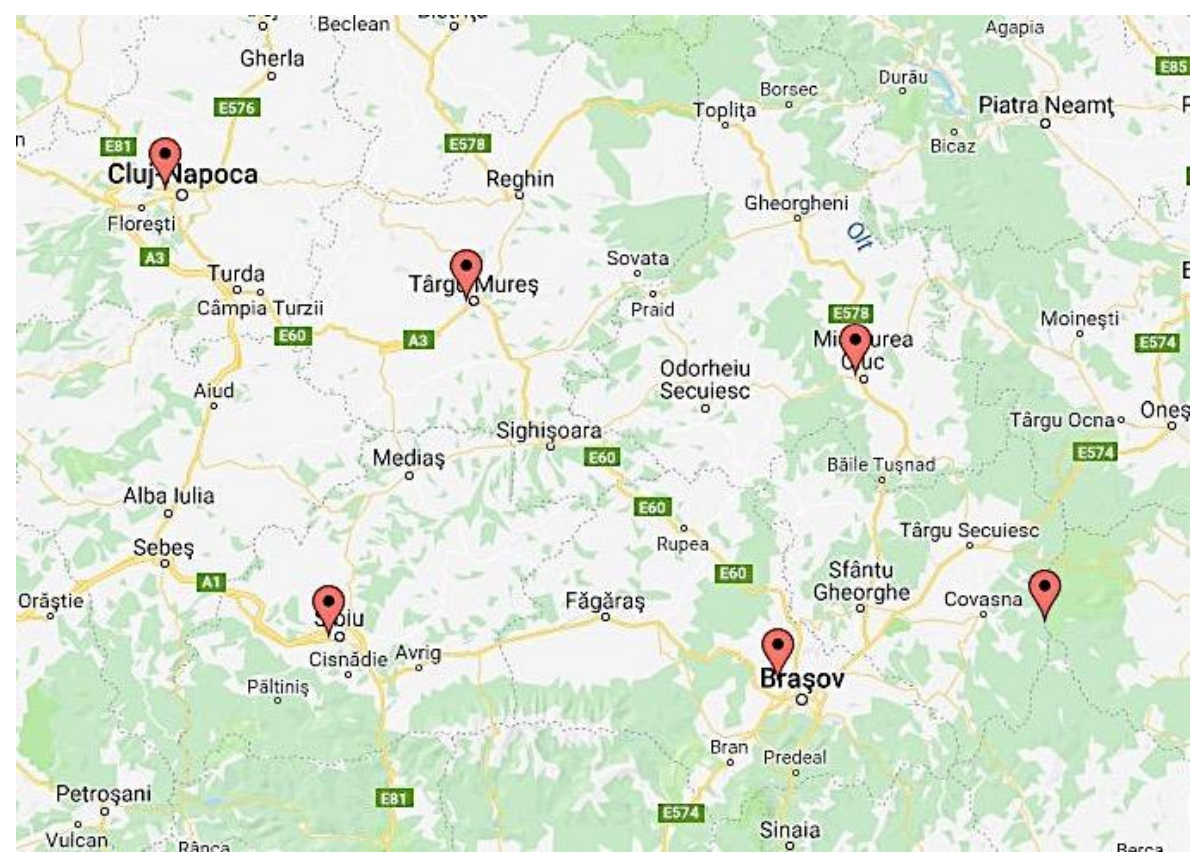

Fig. 1. The locations of studied stations (Google Maps, 2019)

The following precipitation data were studied (yearly and in some cases monthly data): precipitation amounts, maximum 24 hours precipitation, number of days with solid and liquid precipitation, number of days exceeded 0.1, 0.5, 1.0, 2.0, 5.0, 10.0, 20.0, $30.0 \mathrm{~mm}$. 
The main statistical values were calculated using Microsoft Excel software: sum, average, standard deviation, maximum and minimum values. Linear trend was highlighted using Mann-Kendall test analysis (Mann, 1945; Kendall, 1975) and Sen's slope estimate (Sen, 1968), using Makesens soft (Salmi et al., 2002). Two and three parts regressions were analyzed using AnClim software (Stepanek, 2007). Change-point analysis was using to determine if and when a change in a data set occurred and were highlighted with CUSUM charts (which uses cumulative sum and bootstrapping techniques to identify changes) (Taylor, 2000). In order to decide whether time series (yearly amounts of precipitation) have constant variance or not, range-mean plots were created using Gretl software (http://gretl.sourceforge.net). Pálfai Drought Index was calculated in order to characterize the strength and the years of drought. (Pálfai and Herceg, 2011)

\section{RESULTS AND DISCUSSIONS}

\subsection{Summary statistics}

Mean annual precipitation amounts are around $600 \mathrm{~mm}$, except Lăcăuti, where this value exceeds $800 \mathrm{~mm}$. Yearly maximum values are greater than $800 \mathrm{~mm}$, while the minimum precipitation amount is below $500 \mathrm{~mm}$ (Miercurea Ciuc and Lăcăuti) respectivelly $400 \mathrm{~mm}$ (other station). These values are presented in figure 2 .

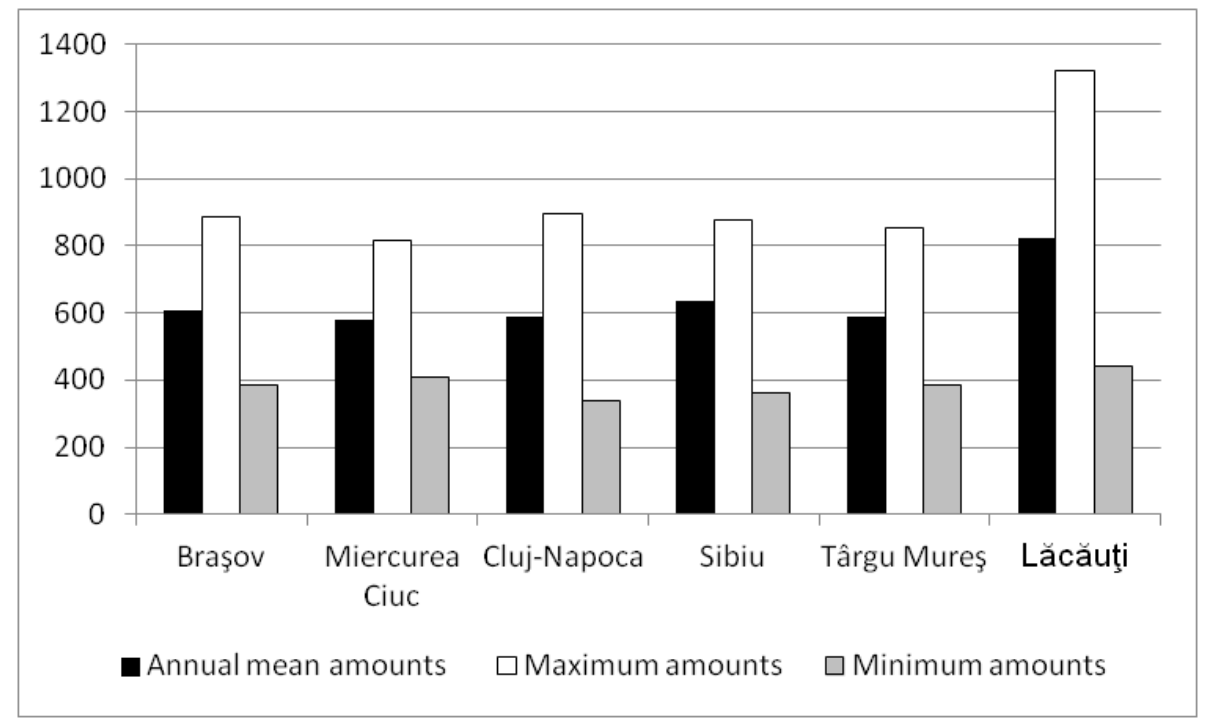

Fig. 2. Mean annual, maximum and minimum precipitation amounts (mm)

The standard deviation of yearly precipitation amount is the greatest in Lăcăuţi $(208 \mathrm{~mm})$ and the smallest in Miercurea Ciuc $(94 \mathrm{~mm})$. The other values are: 106 mm (Braşov), 126 mm Cluj-Napoca, 117 mm (Sibiu) and 107 mm (Târgu Mureş). 
As regard the standard deviation of monthly precipitation amounts, the highest values are registered for summer months $(30-50 \mathrm{~mm}$ in the depressions and 50-60 in Lăcăuţi). In winter and spring this value in many cases is below $20 \mathrm{~mm}$.

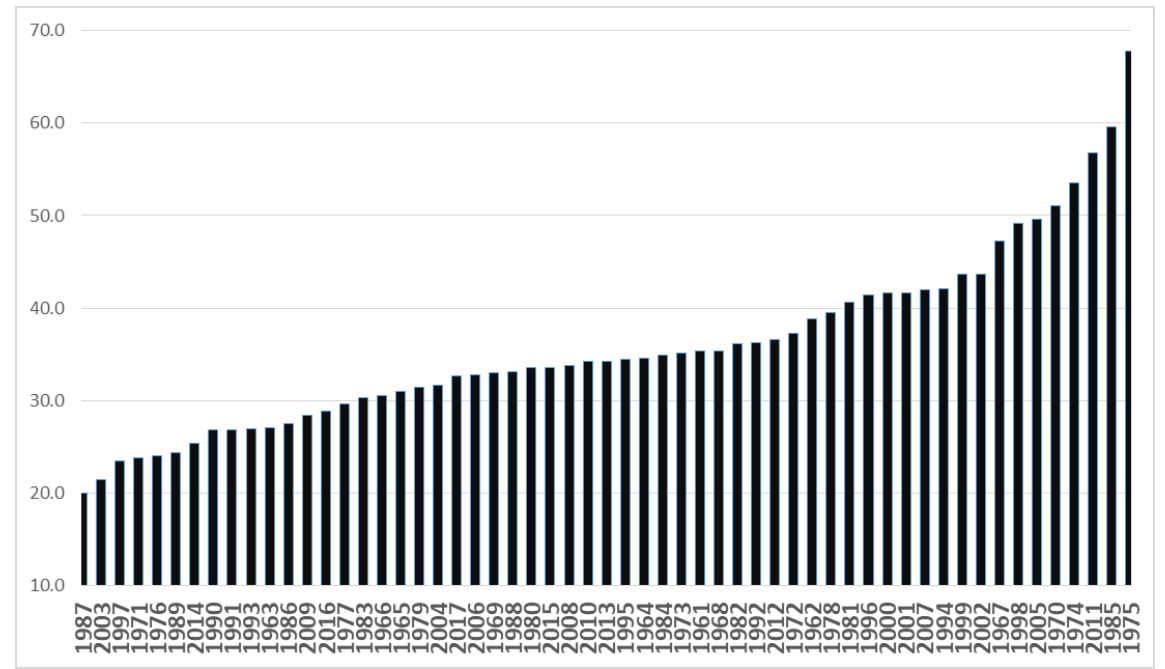

Fig. 3. Maximum precipitation amounts registered in 24 hours in ascending order, between 1961-2017 in Târgu Mureş.

Maximum precipitation amounts registered in 24 hours have highest values in Lăcăuți, the absolute maximum amount was $115.4 \mathrm{~mm}$, measured in 12 June 1969. In the rest of stations this value is below $100 \mathrm{~mm}$. There is no evidence that in last years the amount of precipitation/24 hours it would have increased. Figure 3 . present the years with maximum precipitation amounts registered in 24 hours in ascending order, in Târgu Mureş.

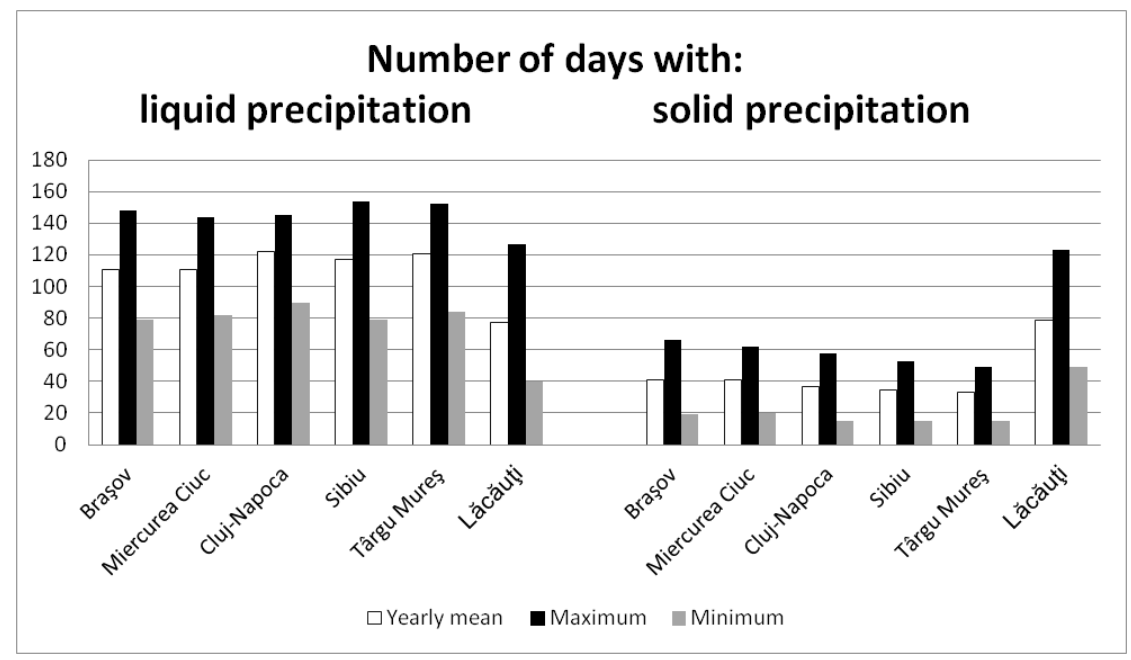


The number of days with liquid precipitation varies between 110-122, and the number of days with solid precipitation varies between 33-41. At Lăcăuţi meteorological station these values are almost equal (77 and respectivelly 79). Figure 4. present the yearly mean, the maximum and the minimum of days with liquid and solid precipitation at these six stations. In 1970 number of days with liquid precipitation exceeded 134 in cases of five stations, even in Lăcăuţi reached 127 . Very few solid precipitation days were registered in 2014, below 21, respectivelly 51 in Lăcăuţi.

The mean values of number of days exceeded 0.1, 0.5, 1.0, 2.0, 5.0, 10.0, 20.0, $30.0 \mathrm{~mm}$ are presented in Tabel 1. The number of days exceded $0.1 \mathrm{~mm}$ are between 140-150 everywere, including Lăcăuţi. In other cases, in Lăcăuţi these values are greater. For instance, the number of days with precipitation amounts higher than 5.0 mm, yearly means are below 40, but in Lăcăuţi reaches 50. In 1970, the number of days with precipitation exceeded 0.1 were above 160, and in Lăcăuţi reaches 212.

Table 1. Yearly means of number of days exceeded different values

\begin{tabular}{|l|c|c|c|c|c|c|c|c|}
\hline $\begin{array}{c}\text { Number of } \\
\text { days with } \\
\text { precipitation: }\end{array}$ & $\geq 0.1 \mathrm{~mm}$ & $\geq 0.5 \mathrm{~mm}$ & $\geq 1.0 \mathrm{~mm}$ & $\geq 2.0 \mathrm{~mm}$ & $\geq 5.0 \mathrm{~mm}$ & $\geq 10.0 \mathrm{~mm}$ & $\geq 20.0 \mathrm{~mm}$ & $\geq 30.0 \mathrm{~mm}$ \\
\hline Braşov & 143 & 111 & 93 & 70 & 37 & 17 & 5 & 2 \\
\cline { 2 - 11 } \\
$\begin{array}{l}\text { Miercurea Ciuc } \\
\text { Cluj-Napoca }\end{array}$ & 144 & 111 & 91 & 69 & 37 & 17 & 4 & 1 \\
\cline { 2 - 10 } Sibiu & 142 & 110 & 92 & 71 & 39 & 18 & 6 & 2 \\
\cline { 2 - 9 } \\
Târgu Mureş & 143 & 112 & 93 & 71 & 37 & 16 & 4 & 1 \\
\hline Lăcăuţi & 146 & 130 & 114 & 90 & 50 & 23 & 8 & 3 \\
\hline
\end{tabular}

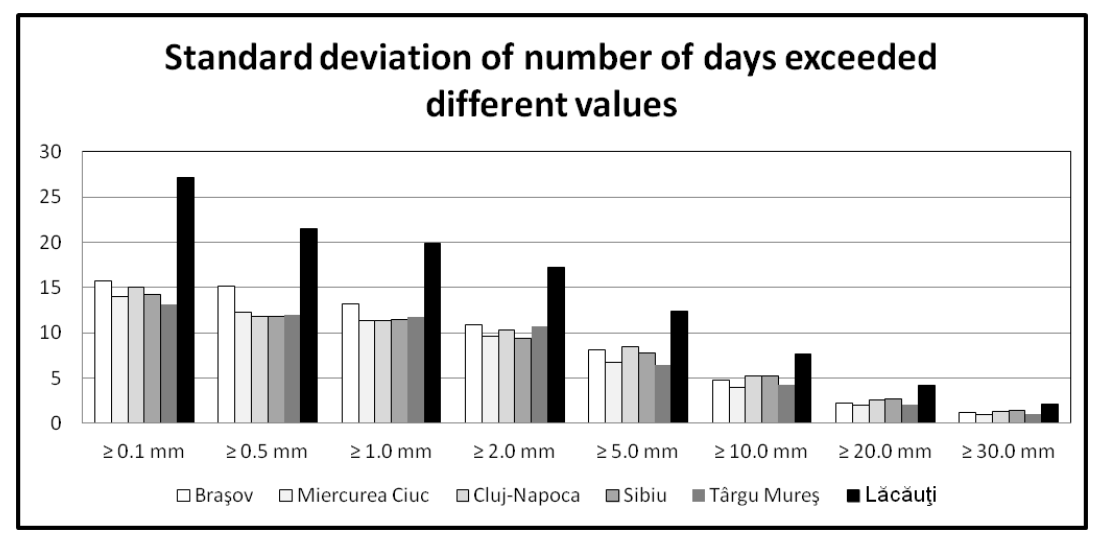

Fig. 5. Standard deviation of number of days exceeded 0.1, 0.5, 1.0, 2.0, 5.0, 10.0, 20.0, $30.0 \mathrm{~mm}$

Also in case of the standard deviation, in mountain area, there are greatest values. As regarding number of days exceeded $0.1 \mathrm{~mm}$ the standard deviations are between 
13-16, except Lăcăuţi, where this value is 27 . The same pattern is in other cases (number of days exceeded 0.5, 1.0, 2.0, 5.0, 10.0, 20.0, $30.0 \mathrm{~mm}$ ), as shown in figure 5 .

\subsection{Trend and changes in time series}

In case of annual precipitation amounts, statistical significant linear trends are in Cluj-Napoca (increasing trend, with Sen's slope estimate equal with 2.19), and in Lăcăuţi (decreasing trend, Sen's slope estimate is -4.93). The trends of monthly precipitation amounts are presented in Tabel 2. Statistical significant increasing trends are in case of March, September and October in Cluj-Napoca, respectively decreasing trends in case of May, July and November in Lăcăuţi.

Table 2. Linear trends (Sen's slope estimate) of monthly precipitation amounts. Statistical significants values (at level 0.05) are presented in bold

\begin{tabular}{|l|c|c|c|c|c|c|}
\hline & Braşov & $\begin{array}{c}\text { Miercurea } \\
\text { Ciuc }\end{array}$ & Cluj-Napoca & Sibiu & Târgu Mureş & Lăcăuţi \\
\hline January & 0.064 & -0.168 & 0.197 & -0.018 & 0.020 & -0.095 \\
\hline February & -0.078 & -0.030 & 0.172 & -0.100 & 0.080 & -0.263 \\
\hline March & 0.262 & 0.179 & $\mathbf{0 . 3 1 3}$ & 0.156 & 0.135 & 0.075 \\
\hline April & 0.036 & 0.200 & 0.264 & 0.223 & 0.044 & -0.030 \\
\hline May & 0.100 & 0.102 & -0.127 & -0.011 & -0.051 & $\mathbf{- 0 . 8 0 3}$ \\
\hline June & -0.105 & 0.191 & 0.324 & -0.108 & 0.239 & -0.845 \\
\hline July & -0.400 & -0.286 & -0.031 & 0.018 & -0.329 & $\mathbf{- 1 . 2 4 1}$ \\
\hline August & -0.001 & 0.260 & -0.186 & 0.046 & -0.177 & -0.264 \\
\hline September & 0.358 & 0.210 & $\mathbf{0 . 7 0 8}$ & 0.170 & 0.387 & -0.018 \\
\hline October & 0.399 & 0.150 & $\mathbf{0 . 5 0 0}$ & 0.296 & 0.263 & 0.215 \\
\hline November & -0.129 & -0.072 & 0.055 & -0.176 & 0.118 & $\mathbf{- 0 . 3 8 8}$ \\
\hline December & 0.016 & 0.045 & -0.064 & 0.008 & -0.073 & -0.168 \\
\hline
\end{tabular}

The major change of different parameters (maximum 24 hours precipitation, number of days with solid and liquid precipitation, number of days exceeded 0.1, $0.5,1.0,2.0,5.0,10.0,20.0 \mathrm{~mm}$ ) are indicated in mountain region, namely in Lăcăuţi. An increasing, statistical significant trend is present in four cases: Braşov, Miercurea Ciuc, Sibiu, Lăcăuţi (Table 3).

Table 3. Linear trends (Sen's slope estimate) of maximum 24 hours precipitation, number of days with solid and liquid precipitation, number of days exceeded 0.1, 0.5, 1.0, 2.0, 5.0, 10.0, $20.0 \mathrm{~mm}$. Statistical significants values (at level 0.05 ) are presented in bold

\begin{tabular}{|l|c|c|c|c|c|c|}
\hline $\begin{array}{c}\text { Number of days } \\
\text { with precipitation: }\end{array}$ & Braşov & $\begin{array}{c}\text { Miercurea } \\
\text { Ciuc }\end{array}$ & $\begin{array}{c}\text { Cluj- } \\
\text { Napoca }\end{array}$ & Sibiu & $\begin{array}{c}\text { Târgu } \\
\text { Mureş }\end{array}$ & Lăcăuţi \\
\hline Max/24h & 0.81 & 0.76 & -0.61 & 0.10 & -0.15 & -0.52 \\
\hline liquid & -0.69 & $\mathbf{3 . 1 4}$ & $\mathbf{2 . 5 5}$ & -0.43 & 1.74 & $\mathbf{- 5 . 5 4}$ \\
\hline solid & $\mathbf{- 4 . 3 3}$ & $\mathbf{- 2 . 7 8}$ & -0.65 & $\mathbf{- 3 . 2 8}$ & -1.72 & $\mathbf{- 5 . 7 4}$ \\
\hline$\geq 0.1 \mathrm{~mm}$ & $\mathbf{- 3 . 0 6}$ & 1.11 & 1.93 & -1.89 & 0.87 & $\mathbf{- 6 . 5 3}$ \\
\hline$\geq 0.5 \mathrm{~mm}$ & -1.21 & 0.17 & $\mathbf{2 . 0 2}$ & -1.19 & 0.06 & $\mathbf{- 6 . 0 4}$ \\
\hline$\geq 1.0 \mathrm{~mm}$ & -0.41 & 0.02 & 1.83 & -1.46 & 0.64 & $\mathbf{- 5 . 1 7}$ \\
\hline$\geq 2.0 \mathrm{~mm}$ & 0.11 & 0.23 & 1.88 & -1.84 & 0.37 & $\mathbf{- 4 . 3 6}$ \\
\hline$\geq 5.0 \mathrm{~mm}$ & 0.74 & 0.00 & $\mathbf{2 . 4 7}$ & -0.39 & 1.10 & $\mathbf{- 2 . 1 4}$ \\
\hline$\geq 10.0 \mathrm{~mm}$ & 0.77 & 0.92 & $\mathbf{1 . 9 7}$ & 1.22 & 1.26 & -0.43 \\
\hline$\geq 20.0 \mathrm{~mm}$ & 0.60 & 1.09 & 1.05 & 1.27 & 0.52 & -1.17 \\
\hline
\end{tabular}


Two parts regression show 1982 as a year in change, except Miercurea Ciuc (1985) and Cluj-Napoca (1971) (Figure 6). In case of all stations, the second part of regression line present an increasing shape. It is remarkable the steep slope of the first part of regression line in Cluj-Napoca.
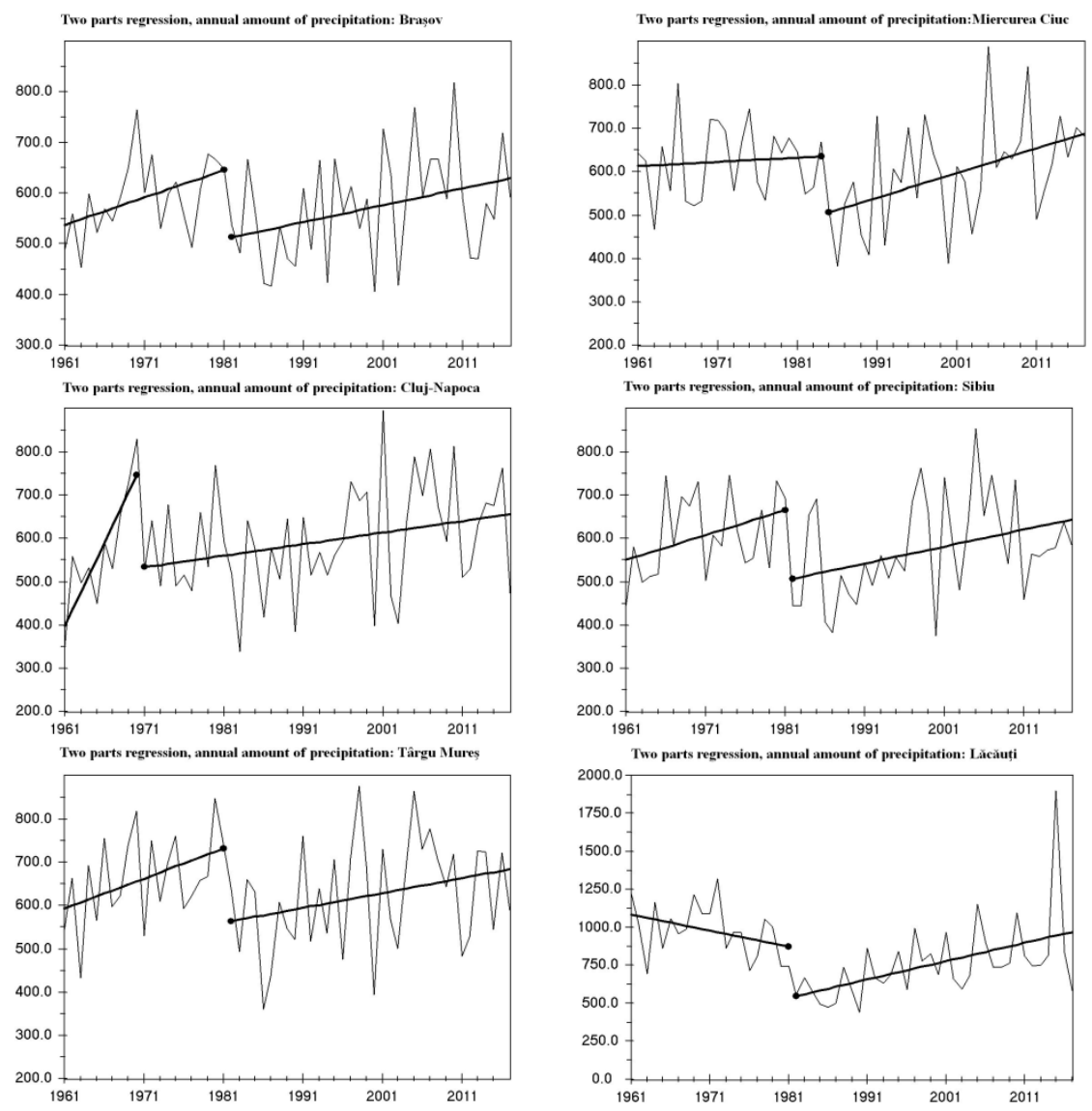

Fig. 6. Two parts regression lines in case of annual precipitation amounts

Main changes in annual precipitation amount (statistical significant values) are registered for Braşov (2005), Târgu Mureş $(1986,1997)$ and Lăcăuţi $(1980,1991)$. CUSUM chart of these stations are presented in figure 7.
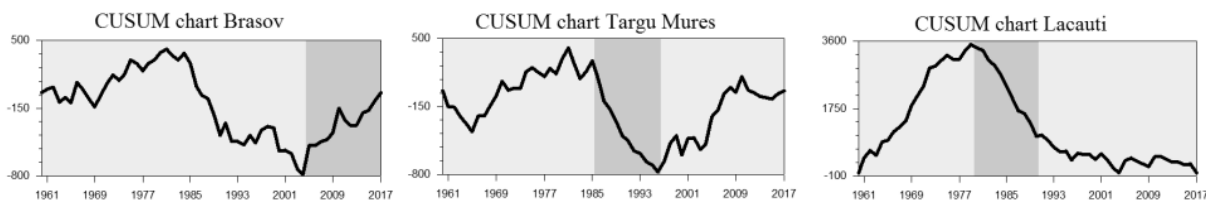

Fig. 7. CUSUM charts of annual precipitation amounts for Braşov,

Târgu Mureş and Lăcăuţi 
Range-mean plots analysis only in case of Cluj-Napoca annual precipitation amounts presents statistical significant values. The upward sloping lines indicate that the variance is increasing in the mean (figure 8.)

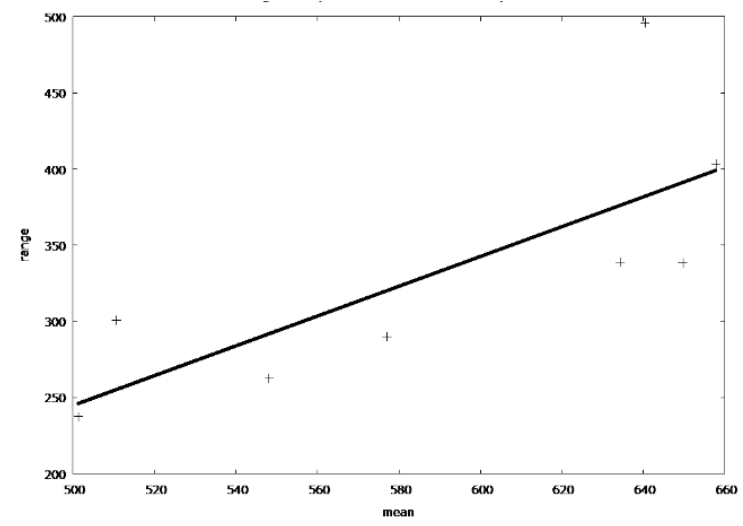

Fig. 8. Range-mean plot for Cluj-Napoca (annual mean precipitation)

\subsection{Pálfai Drought Index (PaDI)}

The importance of Pálfai Drought Index (PaDI) is that it can be applied not only for Hungarian time series, and it use also temperatures time series, not just precipitation data.

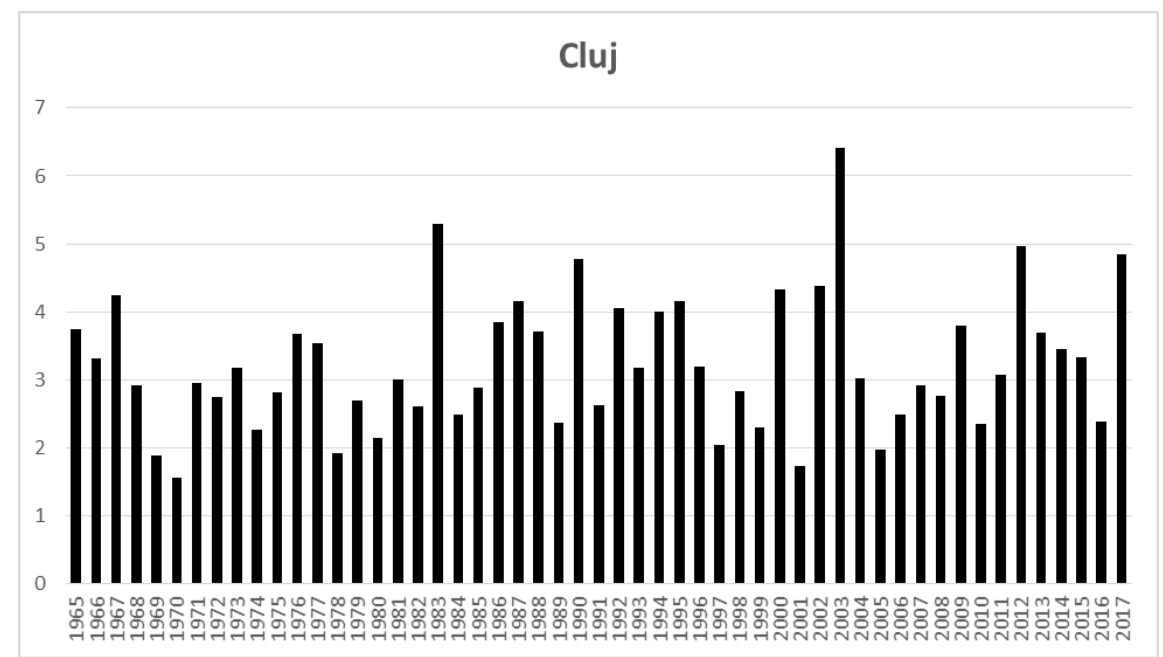

Fig. 9. Pálfai Drought Index for Cluj-Napoca

In case of Lăcăuţi the PaDI values in all years are below 3, which means that no drought was present in this mountain area. No extreme (PaDI above 30), very serious (PaDI between 15 and 30), serious (PaDI between 10 and 15) or heavy drought ( $\mathrm{P}$ between 8 and 10) was registered in the studied stations. Moderate 
drought (PaDI between 6 and 8) was in 1987 (Sibiu and Târgu Mureş), 2003 (ClujNapoca) and 2012 (Sibiu) (figure 9-11.). In some years mild drought (PaDI between 4 and 6) was present: 1967 (Cluj-Napoca), 1983 (Cluj-Napoca, Târgu Mureş), 1986 (Braşov, Sibiu, Târgu Mureş), 1987 (Miercurea Ciuc, Cluj-Napoca), 1988 (Cluj-Napoca, Târgu Mureş), 1989 (Braşov Târgu Mureş), 1990, 1992 (Braşov, Cluj-Napoca, Târgu Mureş), 1994 (Târgu Mureş), 1995 (Cluj-Napoca), 1996 (Târgu Mureş), 2000 (Braşov, Cluj-Napoca, Sibiu, Târgu Mureş), 2002 (ClujNapoca), 2003 (Braşov, Miercurea Ciuc, Sibiu, Târgu Mureş), 2007 (Braşov), 2009 (Târgu Mureş), 2012 (Braşov, Miercurea Ciuc, Cluj-Napoca, Târgu Mureş), 2013, 2014 (Târgu Mureş), 2015 (Sibiu), 2017 (Cluj-Napoca). Except 1967, all these cases of moderate and mild drought are after 1980.

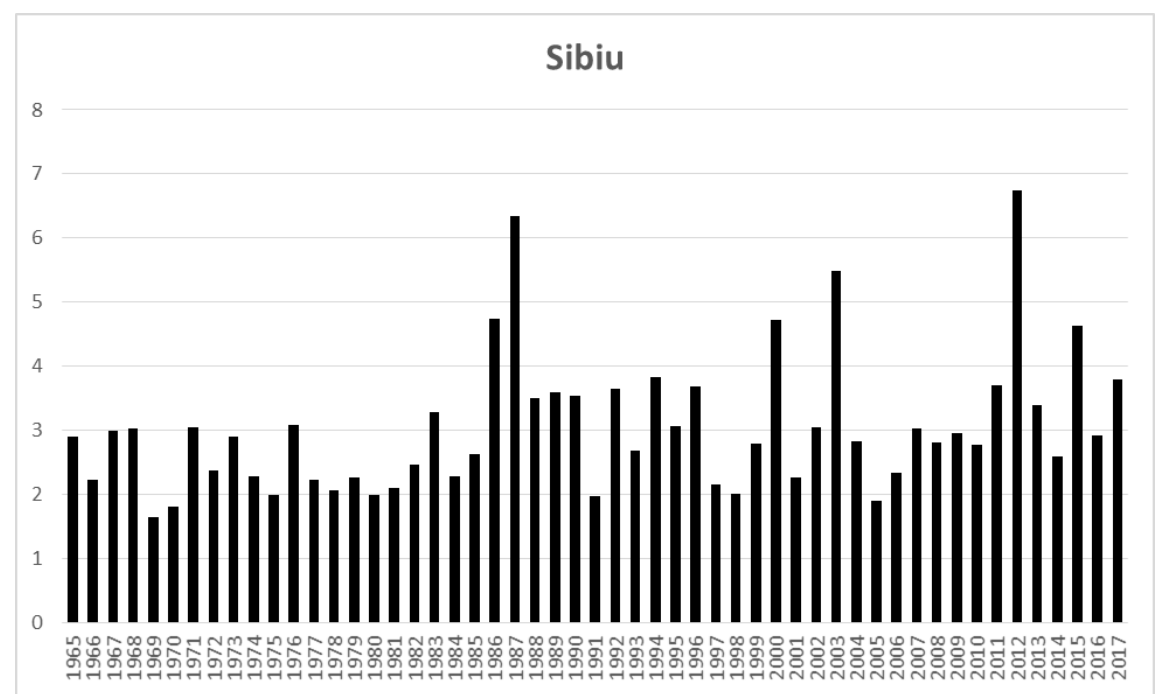

Fig. 10. Pálfai Drought Index for Sibiu

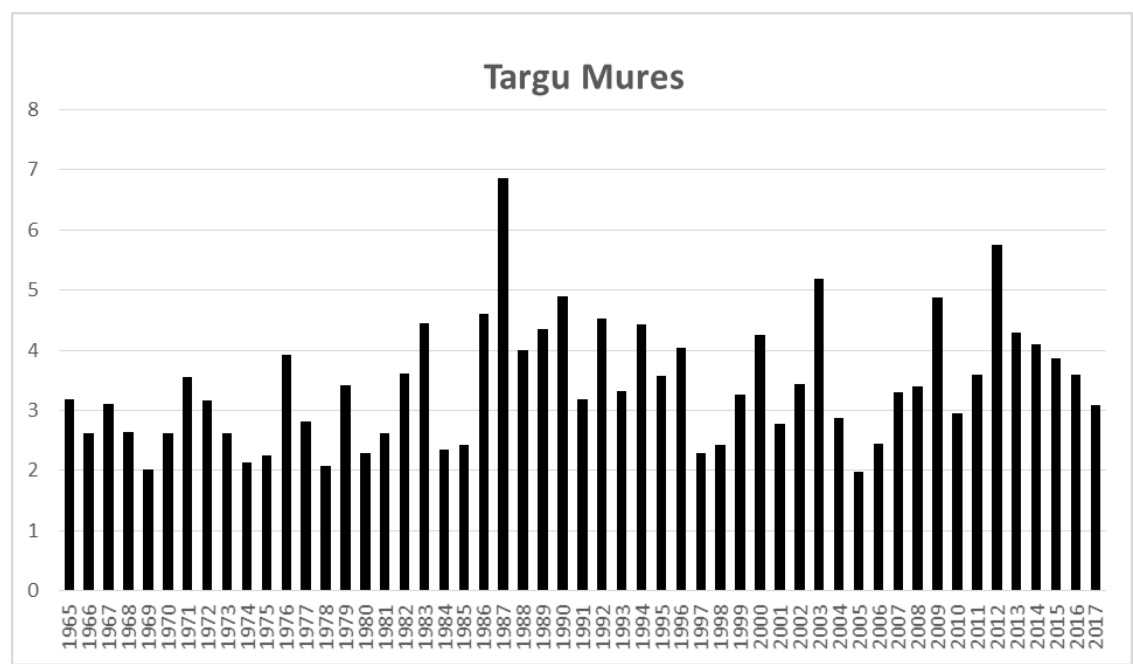




\section{CONCLUSIONS}

Fig. 11. Pálfai Drought Index for Târgu Mureş

The statistical analysis reveal some common aspects as regard the precipitations in the central region of Romania, based on six meteorological stations, of which one is a mountain station: Lăcăuţi. As expected, not only the yearly mean precipitation amounts, but standard deviations are highest in cases of Lăcăuţi precipitation data. Linear trend analysis show that there are a decreasing and statistical significant trends as regard some precipitation data from Lăcăuţi (annual repectivelly May, July and November precipitation amounts, as well number of days with liqiud and solid precipitations, number of days exceeded different values). Increasing trends are in case of yearly and some monthly (March, September and October) precipitation amount of Cluj-Napoca. Two parts regression in four cases highlighted 1982 as year in chang. CUSUM charts of in annual precipitation amounts (statistical significant values) show different moments (years) of changes in case of Braşov, Târgu Mureş, Lăcăuţi. Pálfai Drought Index show that moderate drought was in 1987 (Sibiu and Târgu Mureş), 2003 (Cluj-Napoca) and 2012 (Sibiu). Lăcăuţi was not affected at all of drought. Mild drought appears after 1980 (except 1967 in Cluj-Napoca), and most years with mild drought were indicated for Târgu Mureş (14), while the least occur in Miercurea Ciuc (3).

It seems that mainly the mountain regions are affected by major changes as regarding precipitation in the central region of Romania. Unfortunately, the other mountain meteorological stations do not have such long climatological time series like Lăcăuţi (Bucin meteorological station was founded in 1978, Bâlea Lac in 1979, Roșia Montană in 1983).

\section{REFERENCES}

1. Kendall, M.G. (1975): Rank correlation method, 4th Ed., Charles Griffin, Londres

2. Mann, H.B. (1945): Non-parametric test against trend. Econometrica, 13, pp. 245249.

3. Marin L., Birsan M. V., Bojariu R., Dumitrescu A., Micu D.M., Manea A. (2104), An overview of annual climatic changes in Romania: trends in air temperature, precipitation, sunshine hours, cloud cover, relative humidity and wind speed during the 1961-2013 period. Carpathian Journal of Earth and Environmental Sciences, November 2014, Vol. 9, No. 4, p. 253 - 258.

4. Pálfai, I., Herceg, Á. 2011. Droughtness of Hungary and Balkan Peninsula. Riscuri si Catastrofe, An X 9/2 145-154.

5. Rusz, O (2012), Seven years (2004-2010) precipitation distribution in Transylvania (Romania) from daily data. Geographia Napocensis, Anul VI, Nr.2, pp. 184-189

6. Salmi, T., Määttä, A., Anttila, P.,Ruoho-Airola, T., Amnell T. (2002): Makesens 1.0. Mann Kendall test and Sen's slope estimates for the trend of annual data. Version 1.0. Freeware. Finnish Meteorological Institute, Helsinki. 
7. Sandu I., Mateescu E., Vătămanu V.V. (2010), Schimbări climatice în Romănia şi efectele asupra agriculturii. Editura Sitech, Craiova

8. Sandu I., Pescaru V.I., Poiană I., Geicu A., Cândea I., Țâştea D. (2008), Clima României. Editura Academiei Române.

9. Sen, P.K. (1968): Estimate of the regression coefficient based on Kendall's tau. Journal of American Statistical Association, 63, pp. 1379-1389.

10. Spinoni J., Szalai S., Szemtimrey T., Lakatos M., Bihari Z., Nagy A., Németh Á., Kovács T., Dragan M., Petrovic P., Kržič A., Hiebl J., Auer I., Milkovic J., Štepánek P., Zahradnícek P., Kilar P., Limanowka D., Pyrc R., Cheval S., Birsan M.V., Dumitrescu A., Deák Gy., Matei M., Antalovic I., Nejedlík P., Štastný P., Kajaba P., Bochnícek O., Galo D., Mikulová K., Nabyvanets Y., Skrynyk O., Krakovska S., Gnatiuk N., Tolasz R., Antofie T., Vogt J. (2014), Climate of the Carpathian Region in the period 1961-2010:climatologies and trends of 10 variable. International Journal of Climatology.

11. Stepanek, P. (2007), AnClim - software for time series analysis (for Windows). Dept. of Geography, Fac. of Natural Sciences, Masaryk University, Brno. (http//www.climahom.eu).

12. Taylor, W.A. (2000), Change-Point Analysis: A Powerful New Tool For Detecting Changes (http://www.variation.com/cpa/tech/changepoint.html).

13. *** Meteorological tables from Târgu Mureş Miercurea Ciuc, Braşov, Sibiu, ClujNapoca, Târgu Mureș, Lăcăuti station from period 1961-2017.

14. *** https://www.easymapmaker.com/ Accesed on 31.01.2019 
